\title{
Improving The Quality of Islamic Religious Education Learning Through Revitalization of Teacher Deliberations of Islamic Religious Education Subjects
}

\author{
Lukman Al Hakim, Ulfiah, Fahruroji, Usep Kosasih \\ Nusantara Islamic University, Bandung, West Java, Indonesia \\ Email: lukmanalhakim@gmail.com, ulfiah@uinsgd.ac.id, fahruroji.cholil@gmail.com, \\ usepkosasih77@gmail.com
}

\section{ARTICLE INFO \\ Received: 08-01-2022 \\ Revision: 13-01-2022 \\ Received : 20-01-2022 \\ Keywords: \\ Improving learning \\ quality; Islamic \\ religious education; \\ revitalization; MGMP}

\section{ABSTRACT}

This study aims to examine improvement of the quality of PAI learning through revitalization of the Subject Teacher Conference. This research is based on several thoughts and theories, including; Surah Al-Raad verse 11, which implies that humans must change life for the better through education as a provision for life. Then philosophically, there is a view that education is oriented to the nature of knowledge and a better life. While the theory used is the theory of learning and achievement. In addition, this study uses a qualitative method or approach in which the author tries to examine phenomena and theories from a pragmatic perspective. The results of this study are; the purpose of MGMP Revitalization is to improve learning quality based on the Indonesian Government Regulation number 19 of 2005 concerning National Education Standards. The things that are emphasized are student center methods, professionalism, and active learning. Furthermore, the implementation applied is the application of innovative learning processes, dedication to the mission and vision, empowerment of human resources, and training for teachers. Finally, the problem is that professionalism, knowledge, abilities, and skills are not optimal. At the same time, the solutions and efforts taken are the emphases on having mastery of planning, mastering various competencies, the attitude of teacher responsibility in learning, and high motivation.

\section{Introduction}

The quality of education can be understood philosophically by emphasizing the best practice of education management. The quality of education in question is sustainable quality referring to the quality standards of education by the demands of development and progress of the times. The national governance and educational quality in Europe have a considerable and favorable link that make national governance standards are critical players in improving the quality of educational institutions' outputs (Gerged, \&
Elheddad, 2020). The quality of education, according to Sri, is "a service about the superiority of work results in terms of inputs, processes, outputs and impacts as well as benefits that can be improved through good management" (Haningsih, 2014). In the context of the quality of learning (education), Ansyar said, "there are three determinants of quality, namely people (educators), programs (curriculum) and institutions (leaders)" (Hidayat, 2014). Thus, efforts to fulfill and realize the National Education Standards (SNP) should ideally be supported by qualified

\footnotetext{
How To Cite:

Al Hakim, L., Ulfiah, Fahruroji, Usep Kosasih (2022) Improving The Quality of Islamic Religious Education Learning Through Revitalization of Teacher Deliberations of Islamic Religious Education

E-Issn: Subjects. Journal of Social Sciences, 3(1). https://doi.org/10.46799/jss.v3i1.282

Published By: 2721-5202

Ridwan Institut
} 
personnel with good programs (curriculum) and effective institutions (leaders).

Education as a system education is a complex activity that includes various components related to each other (Nanang, 2006). While Gregory states education aims entail preparing people's minds to comprehend the physical, social, and cultural worlds (Sewell, \& Newman, 2014). Szymkowiak et al, (2021) education plays a key part in the development of citizens in such a society. Motivation, in particular, plays a critical role in learning and is a key determinant in educational success.

The aims of education are, among others, to improve quality service, expertise, and skills, to create a common mindset, to create and develop better work methods, and to foster careers. The quality of Indonesian education is considered by many to be low. This can be seen from several indicators. For example, graduates from schools or colleges are not ready to enter the world of work because of their lack of competence (Kunandar, 2007). Along with the development of information technology and telecommunications, the demand for the quality of human resources is increasingly felt to be very important and needed. Various efforts have been made by the government and the community to improve the quality of these human resources, primarily through education.

Based on a preliminary study, it shows that there are problems that occur in the process of strengthening and improving the quality of PAI learning in Sukabumi, including:

1. In the learning process is still constrained by the weakness of the teacher's ability to empower learning resources and varied learning methods/approaches.

2. On the curriculum side, there is a transition from the 2006 curriculum to the 2013 curriculum. Although PAI subjects have been implemented simultaneously starting in 2013 nationally, there are still problems with understanding at the implementation level so that it affects the quality improvement of the National Education Standards.

3. The lack of attention of PAI teachers on self-development and professional improvement.

4. Student Learning Management. Many teachers are too busy managing the students (management of learners) and pay less attention to the management of student learning (management of learning). So the quality of teaching determines students' success because the quality of teaching depends on how to present the material that must be studied.

5. Facilities and infrastructure. The ideal facilities and infrastructure are owned wholly and entirely by the school, both related to buildings and educational facilities such as books and libraries, Islamic religious education laboratories (PAI), and educational equipment such as computers and projectors in every classroom to realize the use of technology. Information and communication are integrated, systematic, and effective according to the situation and conditions.

6. Internal institutional problems. Considering the existing potential, formal educational institutions have considerable power to organize the teaching and learning process in an effective, efficient, innovative, flexible, and accountable manner. However, the managers of educational institutions such as school principals, vice-principals, teachers, and administrative staff have not been able to take full advantage of potential sources. This happens because the managerial functions have not been running well.

Based on the problems mentioned above, it is undoubtedly a challenge and opportunity as the root of the problem in 
Improving the Quality of Islamic Religious Education Learning (PAI), namely the shift in power values to carry out PAI learning correctly and adequately. This is due to the following factors:

1) The occurrence of modernization of life as a result of a leap of revolution in the field of science and technology.

2) socio-religious relations are only seen from the point of view of usefulness and interest.

3) Information-intensive society, as a result of which the acceptance of Islamic religious education learning can be received by much information from the wider community.

4) An increasingly systemic and open life, resulting in a free lifestyle that leaves religious values, such as promiscuity, free sex.

5) Lack of positive public attention to Islamic religious education. This condition gives rise to the assumption that Islamic religious education lessons hinder the progress of science and new social phenomena that occur in society, such as the existence of associations of young people consisting of elements of high school students who call themselves "anak pang."

6) Less effective PAI learning management, as seen from the teacher's procedures for delivering less organized learning.

These problems and factors occur in the process of improving the quality of PAI learning at the Sukabumi District Junior High School, as can be seen from the symptoms that appear, such as:

a. In students:

a) Low student efficacy in dealing with PAI learning at school

b) Low student learning motivation caused by the lack of non-optimal PAI learning practices

c) Less interested or less interested in learning Islamic religious education, especially in the subject matter of the
Qur'an and the management of corpses.

d) Lack of understanding about Islamic religious education lessons so that there are symptoms of moral decline, conflicts between social groups, and value conflicts. Very few apply Islamic religious education lessons in daily life, such as praying five times a day, reading the Koran, fasting in the month of Ramadan, behaving politely to teachers, likes to fighting with friends.

b. On Islamic Religious Education teachers:

In the teaching and learning process that is carried out, it is not optimal to understand the characteristics of students. When carrying out the teaching and learning process, PAI teachers have not been maximal in:

a) develop competencies that teachers must possess, such as pedagogic competence, personality competence, social competence, and professional competence.

b) applying efficiency and PAI learning methods, as seen from (1) formulation of learning objectives, (2) choosing methods, models, strategies and learning approaches, (3) use of learning resources, (4) making and using teaching aids, (5 ) planning teaching programs, (6) planning and carrying out evaluations.

c) Other obstacles faced in the current era of globalization require strict attention and become challenges that must be resolved and overcome by teachers in order to carry out the learning process correctly and adequately, namely moral decline, disputes between social groups, and value conflicts.

The study about improving teacher quality to teach Islamic Religion subject has been study by Romdon, Sauri, and Sujianto (2020) that evaluates the teacher's performance in the endeavour to improve the quality of education at the senior secondary level. Moreover, Amirullah (2020) 
found one of the barrier factor in improving teachers' quality is participants in sarpras training are limited to a certain number. This, the current study is differ from those two research above since this study is aim to improving the quality of islamic religious education learning through revitalization

\section{Method}

This research is qualitative. While the type of research that researchers use is a type of descriptive research. This descriptive study aims to describe or explain events and events at present. In other words, descriptive research takes problems or focuses on actual problems as they were when the research was carried out (Sugiyono, 2013).

Descriptive research seeks to solve actual problems by collecting data, compiling or classifying it, analyzing and interpreting it. This study tries to solve the problem by describing the problems that occur. This is based on the consideration that the researcher wants to understand, examine indepth, and explain Improving the Quality of Islamic Education Learning through Revitalizing the MGMP of PAI Subjects in Sukabum Regency.

\section{Results And Discussion}

The Deliberation of Islamic Religious Education Subject Teachers (MGMP PAI) in Sukabumi Regency Junior High School as an organization for teachers (educators) who teach Islamic Education Subjects in Public and Private Junior High Schools throughout Sukabumi Regency, West Java Province. MGMP PAI SMP is a forum for teachers (educators) of PAI subjects as a forum for friendship, exchanging information, and sharing experiences between fellow teachers (educators) of SMP PAI subjects to become trustworthy, sincere, moral, and professional educators in carrying out their duties as part of worship to Allah SWT.

The group of Islamic Religious Education (PAI) teachers at the Sukabumi Regency Junior High School realizes the importance of joint efforts in fostering, improving, and developing the professionalism of Islamic Religious Education teachers in order to build a modern society based on faith and devotion to God Almighty and based on Pancasila and the 1945 Constitution. The teachers of Islamic Religious Education agreed to join in a forum formed by the Articles of Association. Based on this agreement, and with the spirit of "Ing Ngarso Sung Tulodho, Ing Madyo Mangun Karso, Tutwuri Handayani," and the motto "from the teacher, by the teacher, and for the teacher and sincere in charity, we teachers of Islamic Religious Education (PAI) Sukabumi Regency together they formed a professional organization called the Islamic Religious Education Subject Teacher Consultation for SMP Sukabumi Regency, abbreviated as MGMP PAI, SMP Sukabumi Regency.

The MGMP for Islamic Religious Education in the Sukabumi Regency Junior High School was established based on a Joint Decree of the Head of the Sukabumi Regency Ministry of Religion and the Sukabumi Regency Education Office Head Number KD. 10.02/IV/PP.01.1/1447/2010 and Number 424/559-Disdik, dated March 19, 2010, domiciled in Sukabumi Regency and is a nonstructural, independent, familial organization, adhering to the principle of advancing together and organized from, by, and for member teachers.

\section{Goals and Programs for Improving the Quality of Learning in PAI SMP in Sukabumi Regency through MGMP Revitalization.}

MGMP PAI SMP Sukabumi Regency is a forum or forum for professional activities for teachers of similar subjects at the studio level or in each school, consisting of two main elements, namely deliberation and teachers of Islamic Religious Education subjects. MGMP PAI SMP Sukabumi Regency formed has AD/ART, which contains at least: Name, Basis, Purpose, Place, Management, membership, program, Organizational Rules. 
(results of an interview with the head of the MGMP).

While the basis for the formation of the PAI MGMP: Law of the Republic of Indonesia Number 20 of 2003 concerning the National Education System. Law Number 14 of 2005 concerning Teachers and Lecturers Government Regulation of the Republic of Indonesia Number 19 of 2005 concerning National Education Standards. Decree of the Minister of Religion Number 3 of 2006 concerning the Organization and Work Procedure of the Ministry of Religion. Regulation of the Minister of National Education Number 16 of 2007 concerning Academic Qualification and Teacher Competence standards. Government Regulation of the Republic of Indonesia Number 55 of 2007 concerning Religious Education and Religious Education. Joint Circular Letter of the Director-General of Primary and Secondary Education Number 781/A/C/U/1993 and the Director-General of Islamic Institutions Number 1/01/ED/1444/1993 concerning Guidelines for the Implementation of MGMP.

For the purposes of the MGMP PAI, SMP in Sukabumi Regency is referred to from the objectives that have been written in the Technical Guidelines, namely: (a) Improving Ukhuwah Islamiyah and wathoniyah (nationality) as well as responsibilities as GPAI to increase faith and piety to Allah SWT for students, (b) Increasing competence GPAI in carrying out learning activities, so that it can support efforts to improve the quality of PAI, (c) Improve the professionalism of PAI teachers in implementing certification and fulfillment of credit scores for functional positions, (d) Fostering the spirit of PAI teachers in improving their abilities and skills in planning, implementing and evaluate PAI learning programs, (e) Accommodate problems faced by PAI teachers in carrying out daily tasks and exchange ideas and seek according to the characteristics of PAI, PAI teachers, schools and the environment, (f) Assist PAI teachers in an effort to meet related needs with PAI learning activities, ( $g$ ) Assist PAI teachers in obtaining educative technical information related to PAI activities both independently and in an integrated manner with other subjects, (h) Help PAI teachers cooperate in improving PAI intra and extra-curricular activities, (i) Assist PAI teachers in obtaining improvement opportunities academic education to meet the demands of Law Number 14 of 2005 concerning Teachers and Lecturers, bro (j) Broaden insight and exchange of information and experience in order to follow the development of science and technology as well as development of PAI teaching methods/techniques.

The PAI MGMP program is prepared and developed by taking into account the problems, challenges, needs, policy capabilities, and regional conditions, the programs developed at least include: (a) Improving the competence of PAI teachers, which include professional, pedagogical, personality, social and leadership, ( b) Career Development and Work Achievement of PAI teachers, both elements of self-development and professional development which include: (1) Implementation of writing/scientific work activities, (2) Finding appropriate technology in the field of education, (3) Making teaching aids/lessons or guidance tools, and (4) Participate in curriculum development activities.

Each academic unit undertakes planning of the learning process, implementation of the learning process, assessment of learning outcomes, and supervision of the learning process to implement an active and dynamic learning process. These laws and government regulations indicate the importance of paying attention to the quality of learning to improve the quality of education in schools. In order to improve the quality of education, in 2005, the government issued RI Regulation number 19 of 2005 concerning National Education Standards. This regulation is the 
government's effort to improve the quality of education in Indonesia.

The government's reasonable efforts need to be followed up by school educational institutions, both public and private, by holding scientific activities that can develop teacher potential through seminars, training, workshops, and others on an ongoing basis so that teachers become professionals who can improve the quality of learning in schools, in turn improving the quality of education will materialize and become a reality, as stated by Muhibin Syah that achievement is "Learning outcomes that cover all psychological domains that change as a result of students' experiences and learning processes" (Muhibbin, 2010).

In other words, based on the understanding above, learning achievement implies a person's ability to master a problem after going through specific exams. Therefore, the term learning is defined as "a process marked by a change in a person. Learning outcomes such as changes in knowledge, attitudes, understanding, behavior, skills, abilities, and abilities as well as changes in other aspects of individual learning" (Sudjana, 2011).

Measurement of student learning success can be determined by measuring the realm of the students themselves, both from the realm of creativity, the realm of taste, the realm of intention, usually known as the cognitive, affective, and psychomotor domains. So the main factors for improving the quality of education are (1) Principal leadership, (2) Teachers, (3) Students, and (4) Curriculum. This means that the principal must have and understand a clear work vision, be able and willing to work hard, have a high work urge, be diligent and steadfast in working, and have strong work discipline.

Furthermore, the maximum involvement of teachers, by increasing the competence and work profession of teachers in seminars, workshops, and training activities so that the results of these activities are applied in schools with the approach that must be taken is "children as the center (stendent center)" of education so that students' competencies and abilities can be explored. So that schools can inventory the strengths that exist in students. All of this will work well if it is organized and packaged in an educational node which is often known as a consistent, dynamic, and integrated curriculum that can enable and facilitate the expected quality standards so that the goals can be achieved optimally.

Based on the description above, it can be explained that principals and teachers have a big responsibility for improving the quality of education in schools. Especially the teacher, because the teacher is the spearhead in the field (in the classroom) who is in direct contact with students in the learning process. Arif Rachman said that there are at least 4 essential things that can improve the quality of learning and continue to the quality of education in schools, namely: (1) Quality improvement: Schools must become a superior place for learning activities, meet and adjust to the demands and expectations of the education law, vision, mission, and demands of the times, systematic and planned efforts towards improvement/improvement of the quality of education, (2) Quality improvement aspects: Fun and challenging learning environment, active participation of students, teachers, parents, and all education stakeholders, responsible management responsible for moral, mandate, human, and capital, have school standards, both national and international, accountable, acceptable, and available human resources, (3) The main factors for improving school quality: Professional educators and education personnel, supported active learning process by learning facilities, participation of students and parents in school programs, supervision $\mathrm{i}$ consistently and consistently (healthy supervision, of programs, human empowerment, and finance), partnerships (government, CB, PT, international agencies and others), (4) Quality improvement support 
programs: Curriculum packaging creativity (intracurricular and extracurricular), students are ready to face the learning program (health, mental, knowledge, togetherness, understanding usefulness), realistic financial conditions and reliable sources.

Thus the paradigm shift must be carried out jointly between leaders, teachers, and employees and all elements of education to have the same steps and strategies, namely creating quality in the work environment, especially the educational work environment. Leaders, teachers, and employees must become a complete team (teamwork) that needs each other and fill each other's shortcomings so that targets (goals) will be created properly.

\section{Implementation of PAI Learning Quality Improvement Goals and Programs through Revitalization of MGMP SMP in Sukabumi Regency}

It is undeniable that the quality of education lies in the teachers' competence. Teachers are professional educators who have duties, functions, and essential roles in the nation's intellectual life. Professional teachers are expected to participate in national development to realize that Indonesian person who fears God Almighty excel in science and technology and have an aesthetic, ethical, noble character and personality. It is no exaggeration to say that teachers primarily determine the future of society, nation, and state. Therefore, the teaching profession needs to be developed continuously and proportionally according to the functional position of the teacher.

In addition, so that applicable regulations carry out the functions and tasks inherent in the available positions of teachers, a Teacher Performance Assessment is needed that ensures a quality learning process at all levels of education. Therefore, the PAI MGMP of SMP in Sukabumi Regency has a program to improve the Professional competence of PAI teachers to develop the implementation of MGMP PAI policies for SMP in Sukabumi City and make MGMPs that can be aligned with organizational success indicators by the 2009 MGMP technical guidelines, the MGMP PAI SMP in Sukabumi Regency implement the following steps: (a) deepening and enrichment of learning materials through literature studies related to PAI, (b) regular discussions on developing issues related to education and Islam, (c) holding dialogues with education experts and Islam and other issues as insight development, and (d) Conduct training on the use of ICT as a model in learning.

The theory of integrated quality management or better known as Total Quality Management (TQM), has recently been widely adopted and used by the world of education. This theory is considered very appropriate in improving the quality of the world of education today. TQM is defined as an approach to running a business that seeks to maximize competitiveness through continuous improvement of products, services, people, processes, and the organizational environment.

There are at least ten characteristics of TQM that are considered essential for improving the world of education, namely: (1) customer focus (internal \& external), (2) quality-oriented, (3) uses a scientific approach, (4) has a long-term commitment, (5 ) teamwork, (6) continuously improving quality, (7) Conducting education and training (8) implementing controlled freedom, (9) having unity of purpose and (10) involving and empowering employees.

As a result, in order to improve the quality of education in schools, efforts have been made through various upgrading activities, seminars, education, training, or workshops. Learning innovations are introduced through these various activities because innovation is a necessity. The development of teaching materials, learning strategies and methods, and learning media, assessment systems, evaluations, and assessments have become the main menu of the world of education. However, from practical experience, these efforts have not 
significantly brought about a change in improving the quality of education in schools.

Therefore, what must be done is continuous improvement related to commitment (Continuous Quality Improvement) and the Continuous Process Improvement process. Commitment to quality begins with a statement of dedication to a shared mission and vision and the empowerment of human resources.

\section{Emerging Problems in the Management of MGMP PAI SMP in Sukabumi District}

Every organization will never be free from problems, especially problems related to management. When viewed from daily life, problems can be caused by internal or external parties. Many parties think that problems that come from external parties are more dangerous so that they are prioritized to be resolved immediately, while problems that come from within (internal) are not too dangerous. This is a wrong view and can lead to the destruction of an organization because the problems that must be watched out for and must be resolved immediately are problems that come from internal. We can see that many political parties are now breaking up due to internal problems. Many companies are not successful because of problems that come from within (internal).

Likewise, PAI MGMP. In reality, experiencing challenges can even mean obstacles in achieving the goals that have been set. The following will explain the problems in the implementation of MGMP PAI SMP management in Sukabumi district in particular, which researchers got through interviews and observations during the study:

a. In terms of planning, several programs have not been optimal in planning, including: (1) In structuring a meeting schedule that is planned every two months it is often not affordable, (2) The program is not designed perfectly because there is no supporting team that prepares the program adequately-short term, as well as long term. b. In terms of Coordination and Organizing, namely: (1) Not optimal coordination in the management of PAI MGMP even sometimes seems to go their way, (2) Unpreparedness of the management to external problems regarding problems that must be solved from each teacher in their respective schools, (3) The diversity of teachers' abilities in ICT skills in modern technology, and (4) The educational background of PAI teachers are from Islamic boarding schools and public schools.

c. In terms of implementation: (1) There are still facilities that have not been fully fulfilled, (2) Some MGMP members are reluctant/do not carry out activities following the program/schedule of activity implementation.

d. In terms of Control and Evaluation

In the organization, one of the most prominent shortcomings is in terms of control and evaluation: (1) the implementation of controls for MGMP PAI in all activities of MGMP PAI in Sukabumi district is not yet optimal, (2) this control should apply to all activities of MGMP PAI, which in its control and evaluation of the implementation of PAI MGMP activities is carried out by related parties, primarily: (a) Central, provincial, and Regency/Municipal Ministry of Religious Affairs officials, (b) National Education department officials, Provincial Education Offices, (c) PAI supervisors, (d) School Principals; (e) Members, and (f) related units.

Meanwhile, the targets of monitoring and evaluation carried out by related parties concern issues related to (1) Program/activity effectiveness, Financial accountability, (3) Conformity of activities with the established program, (4) Involvement of all management with the program being implemented. Stipulate, (5) The linkage of activities with teacher competency improvement, and (6) Processing and maintenance of facilities 
and infrastructure. For evaluation by the authorities has not been touched at all. This slightly hinders and results in less smooth planning for the future.

e. In terms of Budgeting:

From the interview statement of the chairman of the PAI MGMP that the source of the budget is obtained from the PAI teacher's self-help and the rebates from the sale of LKS, several problems arise: (1) Budgeting is not programmed, (b) Dependence only on participating members, so sometimes planned programs goes backward.

MGMP is a forum or forum for professional activities of teachers of similar subjects. MGMP is one type of organization for school teachers that the government recognizes and PGRI. PAI MGMP is a forum or forum for PAI subject teacher activities. This PAI MGMP serves as a forum or means of communication, consultation, exchange of experiences between PAI teachers, increasing knowledge and abilities and skills to foster good cooperative relationships between fellow Islamic Religious Education (PAI) teachers to improve the quality of teachers in learning management to foster the enthusiasm of students in learning and which certainly improves the quality of a teacher which has an impact on improving the quality of graduates (output).

The PAI MGMP is expected to increase the professionalism of teachers in implementing quality learning according to the needs of students. MGMP as a professional subject-based teacher professional forum, programmed and specifically directed to develop standardization of concepts and assessment of subjects nationally. MGMP as a professional subject-based teacher professional forum, programmed and specifically directed to develop standardization of concepts and assess subjects nationally (Saondi, 2010: 75).
The purpose of establishing the MGMP is that teachers should be able to take advantage of and participate in the forum. Improving the quality of teachers through MGMP is an urgent problem to be realized. With the existence of the teacher professional organization or Subject Teacher Consultative Forum (MGMP PAI), it is hoped that it will be able to improve the quality of teachers in carrying out the learning process, which includes monitoring the activities of PAI teachers in planning, implementing and evaluating Islamic religious learning.

The role of MGMP in the development of educational programs in schools is significant because it is a forum for professional teacher activities in increasing knowledge, abilities, and skills. In addition, through this activity, discussions, exchanges of ideas, and experiences with fellow teachers can be carried out to overcome the problems that exist in learning. Through this MGMP, teachers can improve competence by discussing and practicing annual programs (prota), semester programs (prosem), analysis of the subject matter, teaching unit programs, learning methods, evaluation tools, teaching materials, creation, and use of teaching media. It can also be reviewed in this forum. So efforts to improve the quality of teachers can be made through MGMP activities.

As the objectives of holding the MGMP are: (a) To increase the enthusiasm of teachers to improve their abilities and skills in preparing, implementing, and evaluating learning activities, (b) Equalizing the abilities and skills of teachers in carrying out learning activities, to support efforts to increase the distribution of education quality, (c) Accommodate all problems experienced by teachers, in carrying out daily tasks, and find ways to solve them by the characteristics of subjects, teachers, schools, and their environment, (d) Assist teachers in efforts to meet their needs, related to activities learning, and (e) Assisting teachers in obtaining educative technical information, 
relating to activities, curriculum development policies, with the quality of the lessons concerned, and (f) As an exchange of information, and exchanging experiences, in order to follow the development of science and technology, as well as the development of teaching techniques ar. MGMP is a very effective tool in improving the quality of teacher competence and professionalism. This can be seen from the duties and functions of the PAI MGMP forum, namely as a place for teachers to discuss and examine various difficulties in learning. Likewise, the PAI MGMP in Sukabumi Regency also has an essential role in competency development, impacting the quality of PAI MTs teachers in Sukabumi Regency.

\section{Solutions and future improvement efforts Improving the Quality of PAI Learning through Revitalization of MGMP SMP in Sukabumi Regency}

From the exposure of research data as the researchers described in previous chapters, it was found that research findings related to the problems that arise in the management of PAI MGMP in Sukabumi district; the following researchers describe solutions to overcome the problems needed in implementing PAI development management in junior high schools as following:

a. Efforts to optimize management from planning to evaluation are attempted to run according to the program created.

b. Program Relevance

The management strives to adapt the work program to the needs and aspirations of members by responding to and accommodating the needs of members and the challenges of the realities of work in the work environment so that members support policies. When members pursue organizational goals, they must also satisfy their individual needs. Individual needs and goals must be balanced with the needs and goals of the organization.
In general, the development of the MGMP work program is closely related to the duties and responsibilities that must be realized, namely: (1) providing motivation to teachers to participate in every activity in the organization, (2) improving the abilities and skills of teachers in carrying out learning activities so that they can support efforts to improve and equal distribution of education quality, (3) providing consultative services in overcoming teacher problems in learning activities, (4) supporting the fulfillment of teacher needs related to learning activities, especially regarding teaching materials and materials, (5) disseminating information on all policies related to curriculum and subject development; and plan, implement, evaluate and report the results of MGMP activities and determine the follow-up,

c. Management Readiness (Physical and Mental),

d. MGMP Activity Funding and

e. Facilities and infrastructure

To improve the quality and quantity of teaching and learning activities carried out by teachers as educational staff, the teaching profession must have and master the planning of teaching and learning activities, carry out planned activities and evaluate the results of the teaching and learning process. For the learning process to be carried out effectively and efficiently, the teacher has an important task and role in delivering his students to achieve the expected goals.

The ability of teachers to plan and implement the learning process is a significant factor in achieving teaching objectives. The skill of planning and implementing the teaching and learning process is closely related to the duties and responsibilities of the teacher as an educating teacher. Therefore, it is proper for teachers to have various competencies related to their duties and responsibilities. 
This MGMP organization aims to improve the quality and professionalism of teachers in their respective groups. The activities in this group are arranged in a pretty good schedule. Unfortunately, there is no formal linkage and relationship between the teachers in this MGMP and PGRI.

The purpose of the MGMP is to improve the quality and professionalism of teachers. The objectives of this MGMP are: (a) To motivate teachers to improve their abilities and skills in planning, implementing, and evaluating learning programs in order to increase self-confidence as professional teachers, (b) To state the abilities and skills of teachers in carrying out learning so that they can support business activities. increasing equity in the quality of education, (c) Discussing the problems faced and experienced by teachers in carrying out daily tasks and seeking alternative solutions according to the characteristics of each subject, teachers, school conditions, and the environment. (d) Assisting teachers in obtaining educative technical information related to science and technology, curriculum activities, methodologies, and testing systems by the subjects concerned, (e) Sharing information and experiences from the results of their workshops, symposia, seminars, training, classroom action research, references, and others. Professional activities that were discussed together, (f) Able to describe and formulate the school reform agenda (school reform), mainly the focus on classroom reform, so that it proceeds to a practical learning reorientation, $(\mathrm{g})$ Able to describe and formulate the school reform agenda (school reform), mainly the focus on classroom reform, so that it proceeds to reorient effective learning, (g) Able to describe and formulate the school reform agenda (school reform), mainly focus on classroom reform, so that it proceeds to the reorientation of effective learning.

The MGMP has the following objectives: (1) to foster teacher enthusiasm to improve abilities and skills in preparing, implementing, and evaluating teaching and learning activities programs to increase self-confidence as a teacher. (2) equalizing the abilities and skills of teachers in carrying out teaching and learning activities so that they can support efforts to improve and equalize the quality of education. (3) discuss the problems teachers face in carrying out their daily tasks and find solutions by the characteristics of the teacher's subjects, school conditions, and the environment. (4) assisting teachers in obtaining educative technical information related to science and science and technology activities, curriculum implementation activities, methodologies, and evaluation systems by the subjects concerned, and (5) sharing information and experiences to adapt to the development of science and technology.

\section{Conclusion}

From the results of the study, it can be concluded that the Subject Teacher Consultation (MGMP) in improving the quality of PAI teachers in Sukabumi Regency can be done in several ways, including participating in discussions on educational issues, participating in practical learning training, attending training or seminars on increasing teacher professionalism. The implementation of quality management has not been carried out optimally or has not implemented the entire system by the provisions. Thus the performance of the Sukabumi District MGMP can still be improved through the development of quality management, as supported by a good documentation system and empowering teachers to develop more in their performance and competence.

\section{References}

Amirullah, Y. (2020). The Synergy of Competency Strategy of Islamic Education Teacher to Improve the Quality of Education and Character of Students in Millenial Era. Educan: Jurnal Pendidikan Islam, 4(1), 135-152.Google Scholar 
Gerged, A., \& Elheddad, M. (2020). How can national governance affect education quality in Western Europe? International Journal of Sustainability in Higher Education. Google Scholar

Haningsih, Sri. (2014). Implementasi Program Mutu Pendidikan Dalam Meningkatkan Budaya Akademik Di Madrasah Aliyah Sunan Pandanaran (MASPA) Sardonoharjo Ngaglik Sleman DIY. EL TARBAWI, 8(1), 27-40. Google Scholar

Hidayat, Rakhmat. (2014). Sosiologi Pendidikan Emile Durkheim. Depok: RajaGrafindo Persada. Google Scholar

Kunandar. (2007). Guru Professional. Jakarta: PT. Rajagrafindo Persada.

Muhibbin, Syah. (2010). Psikologi pendidikan dengan pendekatan baru. Bandung: PT Remaja Rosdakarya. Google Scholar

Romdon, R., Sauri, U. S., \& Sujiarto, H. (2020). The Effectiveness of Improving the Performance of Teachers of Islamic Religion Education Through Teacher Certification Programs in SMA/SMK in Bogor District. International Journal of Nusantara Islam, 8(2), 215-225. Google Scholar

Sewell, K., \& Newman, S. (2014). What is education. Education Studies: An Issue Based Approach. Google Scholar
Sudjana, Nana. (2011). Penilaian hasil dan proses belajar mengajar. Bandung: Rosda Karya, 180. Google Scholar

Sukmadinata. S. (2019). Pengembangan Kurikulum. Bandung: Remaja Rosdakary.

Sugiyono, Dr. (2013). Metode penelitian pendidikan pendekatan kuantitatif, kualitatif dan R\&D. Google Scholar

Szymkowiak, A., Melović, B., Dabić, M., Jeganathan, K., \& Kundi, G. S. (2021). Information technology and Gen Z: The role of teachers, the internet, and technology in the education of young people. Technology in Society, 65, 101565. Google Scholar

Undang-Undang Guru dan Dosen 2005 Bab VI tentang Standar Pendidik dan Tenaga Kependidikan pasal 28

Undang-Undang RI Nomor 20 tahun 2003 Tentang Sistem Pendidikan Nasional pada bab II pasal 3 (Dirjen Pendidikan Islam Depag RI, 2006), h. 8-9)

Undang-undang Sistem Pendidikan Nasional Nomor 20 Tahun 2003, tentang Sistem Pendidikan Nasional.

\section{Copyright holder:}

Lukman Al Hakim, Ulfiah, Fahruroji, Usep Kosasih (2022)

First publication right:

Journal of Social Science

This article is licensed under:

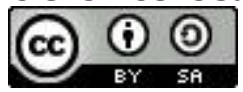

